\title{
Radiocarbon
}

1989

\section{RADIOCARBON DATING OF DEEP-SEA SEDIMENTS: A COMPARISON OF ACCELERATOR MASS SPECTROMETER AND BETA-DECAY METHODS}

\author{
G A JONES
}

Woods Hole Oceanographic Institution Woods Hole, Massachusetts 02543

\author{
A J T JULL, T W LINICK and D J DONAHUE \\ NSF-Arizona Accelerator Facility for Radioisotope Analysis \\ Department of Physics, University of Arizona
}

Tucson, Arizona 85721

\section{INTRODUCTION}

Radiocarbon dating (Libby, 1955) has been an important tool in the marine sciences since the early 1950s (eg, Arrhenius, Kjellberg \& Libby, 1951; Ericson et al, 1956; Broecker, Ewing \& Heezen, 1960; Emery \& Bray, $1962)$ and the basic principles and analytic procedures of the method have changed little. In the late 1970s, the Accelerator Mass Spectrometer (AMS) method of ${ }^{14} \mathrm{C}$ dating was developed (Bennett $e t$ al, 1977, 1978), the major advantages being that samples several thousand times smaller than needed for beta-decay counting can be dated, and analysis time is reduced to ca 1 hr from the 1-6 days needed for beta-decay methods.

The deep-sea sediment record is ideally suited for ${ }^{14} \mathrm{C}$ dating by AMS, as there is often insufficient material available for both dating by beta-decay methods and performing other sedimentologic analyses. In many regions of the ocean, there is a significant component of eolian or glacially transported detrital carbonate, or reworked fine-grained biogenic carbonate (ie, ${ }^{4} \mathrm{C}$-dead material). This material is mixed with contemporaneously produced biogenic carbonates, resulting in erroneously old, and often uninterpretable, ${ }^{14} \mathrm{C}$ ages when bulk-sediment analyses are made.

Despite the wide acceptance and clear utility of AMS dating in the marine geological sciences (eg, Broecker et al, 1984; Duplessey et al, 1986; Bard et al, 1987; Andrée et al, 1986), there has been no direct comparison of this method with the well-established beta-decay method of ${ }^{14} \mathrm{C}$ dating deep-sea sediments.

Within the past three years, Woods Hole Oceanographic Institution has become one of the largest users of the National Accelerator Facility at the University of Arizona, submitting some 300-400 samples annually. Most of these samples are carbonates obtained from the various components found in deep-sea sediments. Before undertaking AMS studies, we conducted a study in 1984-1985 to compare directly AMS and beta-decay 
methods of dating deep-sea sediments, as well as to compare the iron-carbide (Linick et al, 1986) and graphite (Jull et al, 1986; Slota et al, 1987) methods of target preparation for AMS. This was an empirical study designed to identify the potential problems and/or advantages of using either method for a wide range of deep-sea-sediment studies, and obtain a base line of intercompared AMS and beta-decay ${ }^{14} \mathrm{C}$ dates from the same deep-sea sediment core. Fourteen conventional and 21 AMS ${ }^{14} \mathrm{C}$ analyses are reported from Equatorial Atlantic core V30-41 K.

\section{METHODS}

\section{V30-41K Core Description}

Kasten core V30-41 K $\left(00^{\circ} 13^{\prime} \mathrm{N}, 23^{\circ} 4^{\prime} \mathrm{W}\right.$; 3874m water depth, ) was collected from the eastern flanks of the mid-Atlantic Ridge by Lamont-

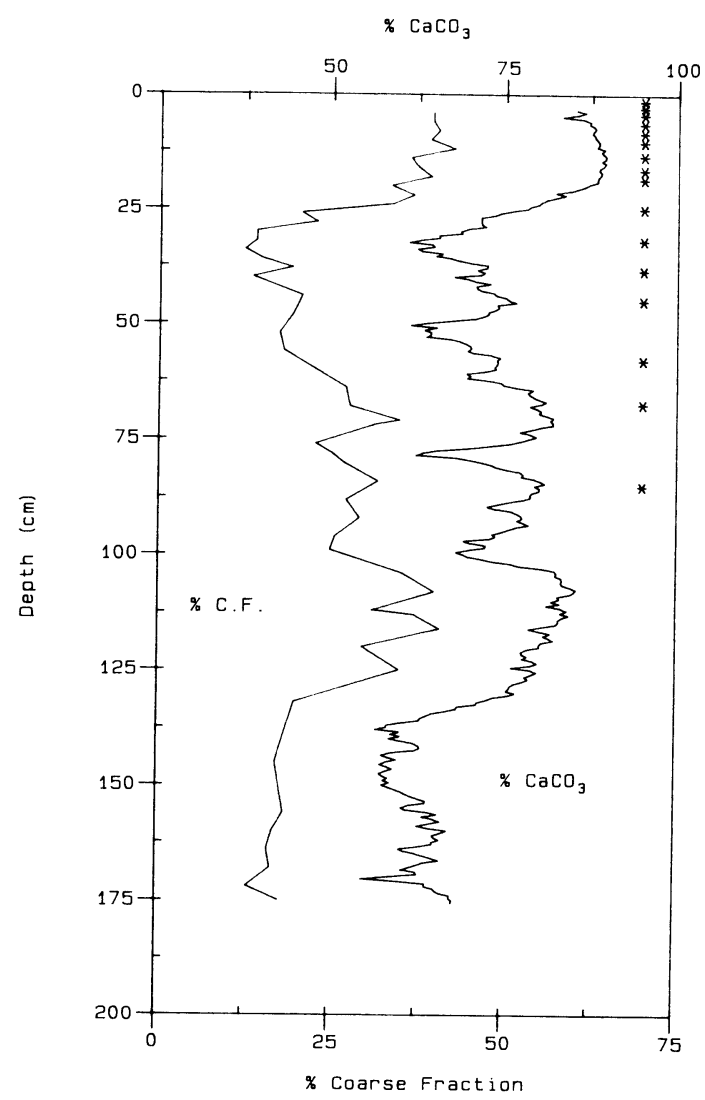

Fig 1. Coarse-fraction $(>63 \mu)$ and $\mathrm{CaCO}_{3}$ percentage determinations. $\mathrm{CaCO}_{3}$ percentages were determined at $0.5 \mathrm{~cm}$ intervals using the method of Jones and Kaiteris (1983) Coarse-fraction percentages were determined at ca $4 \mathrm{~cm}$ intervals. Intervals sampled for ${ }^{14} \mathrm{C}$ determinations are marked with an asterisk $\left(^{*}\right)$. Exact depths of these analyses are given in Table 1 . 
Doherty Geological Observatory in 1973 . This core is $176 \mathrm{~cm}$ long and has been extensively studied (Jones \& Ruddiman, 1982). It is an average Equatorial Atlantic core, with an approximately linear sedimentation rate over the past 35,000 years, no visible anomalous sediment features and no extensive carbonate dissolution. This core contains no evidence of downslope reworking, and is from a region relatively free of detrital carbonate $\left(\right.$ ie ${ }^{14} \mathrm{C}$-dead) input. Thus, $\mathrm{V} 30-41 \mathrm{~K}$ was chosen as a good direct test of betadecay and $\mathrm{AMS}{ }^{14} \mathrm{C}$ dating.

For this study, we have analyzed both the bulk (total) $\mathrm{CaCO}_{3}$ and the $>150 \mu$ fractions by AMS, and bulk $\mathrm{CaCO}_{3}$ by beta-decay methods because these are the two most commonly used fractions for paleoceanographic studies. Most beta-decay ${ }^{14} \mathrm{C}$ dates from deep-sea sediment cores are obtained from the total carbonate fraction, while most paleoceanographic information is obtained from analyses of planktonic and benthonic foraminifera in the $>150 \mu$ size fraction. Figure 1 shows the downcore profiles of coarse-fraction ( $>63 \mu$, entirely composed of planktonic and benthonic foraminifera) and total-sediment carbonate percentages for this core.

\section{Beta-Decay Dating Techniques}

With conventional methods of ${ }^{14} \mathrm{C}$ dating, ca $10-40 \mathrm{~g}$ of carbonate (ie, ca $1-4 \mathrm{~g} \mathrm{C}$ ) are acidified, and the $\mathrm{CO}_{2}$ is most often converted to either acetylene (Suess, 1954) or benzene (Barker, 1953). Depending upon the age of the sample and the precision desired, a sample is counted from 1-6 days. On average, most ${ }^{14} \mathrm{C}$ laboratories achieve an analytical precision of $\pm 4-$ $7 \%$ for material of modern age. For a more thorough treatment of the principles of ${ }^{14} \mathrm{C}$ dating by the beta-decay method, see, eg, Libby (1955), Faure (1977) and Berger and Suess (1979).

We used 14 beta-decay analyses of bulk sediment (Table 1, Fig 2). Sample sizes ranged from $20-40 \mathrm{~g}$. The results are reported as conventional ${ }^{14} \mathrm{C}$ ages (Stuiver \& Polach, 1977), and no reservoir corrections have been applied (Stuiver \& Ostlund, 1980).

\section{AMS Dating Techniques}

For AMS ${ }^{14} \mathrm{C}$ dating of marine sediments, $10-30 \mathrm{mg}$ of carbonate (ie, 1-3mg of $\mathrm{C}$ ) were used. $\mathrm{CO}_{2}$ was produced by acidification with phosphoric acid in vacuo. The $\mathrm{CO}_{2}$ was reduced to $\mathrm{CO}$ over hot $\mathrm{Zn}$ and further reduced over hot Fe to iron-carbide (Linick et al, 1986) or elemental carbon (Jull et al, 1986; Slota et al, 1987). The analytical precision obtained with the ironcarbide targets is $\pm 20-30 \%$ for modern materials, and the background is ca $30,000 \mathrm{yr}$. This method was used by the US National Accelerator Facility in Tucson, Arizona from May 1982 to late 1984. Since late 1984, this facility has used graphite targets. The analytical precision of this method is $\pm 5-10 \%$ for modern material, and the background is ca $45,000 \mathrm{yr}$.

We obtained 21 AMS ${ }^{14} \mathrm{C}$ dates from Equatorial Atlantic core V30-41 K (Table 1, Fig 2). The results are reported as conventional ${ }^{14} \mathrm{C}$ ages (Stuiver \& Polach, 1977), and no reservoir corrections were applied (Stuiver \& Ostlund, 1980). 
TABLE 1

Radiocarbon ages for Equatorial Atlantic core V30-41 K

\begin{tabular}{|c|c|c|c|c|}
\hline Depth $(\mathrm{cm})$ & $\begin{array}{c}\text { Beta-decay* } \\
\text { (total sediment) }\end{array}$ & $\begin{array}{c}\text { Graphite } \\
\text { (total sediment) }\end{array}$ & $\begin{array}{c}\text { Accelerator** } \\
\text { Graphite } \\
(>150 \mu)\end{array}$ & $\begin{array}{l}\text { Iron-carbide } \\
\quad(>150 \mu)\end{array}$ \\
\hline $0-1$ & $5800 \pm 260+$ & & & \\
\hline $1-2$ & & & $6170 \pm 90$ & $6510 \pm 290$ \\
\hline $2.5-4$ & $(2100 \pm 120) \dagger$ & & & \\
\hline 4-5 & $(2420 \pm 200) \dagger$ & & & \\
\hline $6-7$ & $2490 \pm 80_{+}^{+}$ & $2500 \pm 70$ & $2760 \pm 80$ & \\
\hline $\begin{array}{c}8-9 \\
10-11\end{array}$ & $(3750 \pm 230) \dagger$ & & $2920 \pm 70$ & \\
\hline $13-14$ & $4490 \pm 100_{+}^{+}$ & $4340 \pm 80$ & $4830 \pm 80$ & $5610 \pm 260$ \\
\hline $\begin{array}{l}13-14 \\
18-19\end{array}$ & $(7890 \pm 350) \dagger$ & & $4520 \pm 130$ & \\
\hline $24-26$ & $(10,870 \pm 360) \dagger$ & & & \\
\hline $31-32$ & $(12,610 \pm 610) \dagger$ & & & \\
\hline $32-33$ & & $12,860 \pm 160$ & $13,930 \pm 170$ & $14,400 \pm 600$ \\
\hline $\begin{array}{l}38-39 \\
44-46\end{array}$ & $\begin{array}{l}(15,230 \pm 840) \dagger \\
(19,080 \pm 920) \dagger\end{array}$ & $18,150 \pm 210$ & $17,740 \pm 190$ & $18,200 \pm 1000$ \\
\hline $57.5-59$ & $22,100 \pm 290 \S$ & & & \\
\hline $66-67.5$ & $25,000 \pm 310 \S$ & & & \\
\hline $68-69$ & & $30,450 \pm 790$ & $27,840 \pm 480$ & $29,600 \pm 3900$ \\
\hline $\begin{array}{l}84-85 \\
84-87\end{array}$ & $25,040 \pm 460_{+}^{+}$ & $36,120 \pm 1380$ & $33,970 \pm 760$ & $>30,000$ \\
\hline
\end{tabular}

* Dates in parentheses have been reported previously in Jones and Ruddiman (1982). ** Analyses made at University of Arizona, Tucson Accelerator Facility between 1984-85. Conventional ${ }^{14} \mathrm{C}$ ages are given with an assumed ${ }^{13} \mathrm{C}$ value of $0 \%$ used for $\delta^{13} \mathrm{C}$ correction to $-25 \%$.

† Analyses made at Lamont-Doherty Geological Observatory radiocarbon laboratory in 1978. Conventional ${ }^{14} \mathrm{C}$ ages are given with an assumed ${ }^{13} \mathrm{C}$ value of $0 \%$ used for $\delta^{13} \mathrm{C}$ correction to $-25 \%$.

+ Analyses made at Beta Analytic between 1983-85. Conventional ${ }^{14} \mathrm{C}$ ages are given with measured ${ }^{13} \mathrm{C}$ values used for $\delta^{13} \mathrm{C}$ correction to $-25 \%$.

$\S$ Analyses made at Beta Analytic between 1983-85. Conventional ${ }^{14} \mathrm{C}$ ages are given with an assumed ${ }^{13} \mathrm{C}$ value of $0 \%$ used for $\delta^{13} \mathrm{C}$ correction to $-25 \%$.

\section{RESULTS AND DISCUSSION}

\section{Core-top Ages}

Most deep-sea sediment studies assume that the sediment-water interface (ie, the "true" coretop) is either recovered infrequently or is disturbed by coring devices (eg, Wrath, 1936; Burns, 1963; Hopkins, 1964; Emery \& Hulsemann, 1964; Weaver \& Schultheiss, 1983; Blomqvist, 1985). Estimates range from no sediment to as much as $\mathrm{lm}$ missing due to this problem. V30-41 K exhibits a different type of problem. The upper $2.0 \mathrm{~cm}$ of this core was slightly darker than the underlying sediment but otherwise did not appear unusual. The $0-1 \mathrm{~cm}$ level of this core yielded a beta-decay ${ }^{14} \mathrm{C}$ date of $5800 \mathrm{yr}$, which was clearly anomalous when compared to the ages of the underlying levels (Table 1). The 1-2cm level was AMS dated on the $>150 \mu$ fraction. Both the iron-carbide and graphite targets revealed anomalously old ages (Table 1). Below the 2cm level, conventional and AMS dates yielded ages, and an age-depth profile, that would be expected for a core with a $2.40 \mathrm{~cm} / 1000 \mathrm{yr}$ sedimentation rate and a bioturbated mixed layer of ca 4cm (Jones \& Ruddiman, 1982; Peng et al, 1979). 


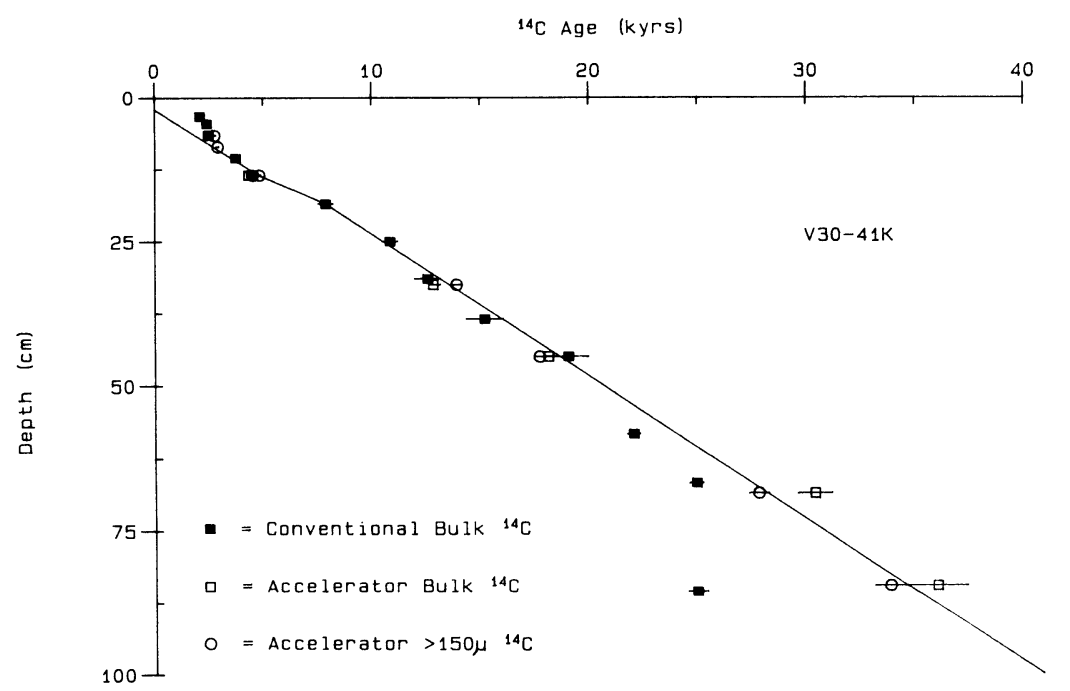

Fig 2. Age-depth plot for ${ }^{14} \mathrm{C}$ analyses listed in Table 1. Fit is based on a $2.4 \mathrm{~cm} / 1000 \mathrm{yr}$ sedimentation rate from 2 (ie, true coretop) $-13.5 \mathrm{~cm}$, a $1.6 \mathrm{~cm} / 1000 \mathrm{yr}$ sedimentation rate from $13.5-18.5 \mathrm{~cm}$; and a $2.45 \mathrm{~cm} / 1000 \mathrm{yr}$ sedimentation rate from $18.5-85.0 \mathrm{~cm} .1 \sigma$ errors are given by horizontal bars through each data point. Note $4-6 \mathrm{~cm}$-thick mixed layer at the coretop, and the increasingly divergent accelerator and conventional ${ }^{14} \mathrm{C}$ ages below $60 \mathrm{~cm}$.

We suspect that during core recovery and shipboard storage, dewatering of the core carried sediment upwards along the core liner and this sediment was redeposited onto the top of the core. This mechanism of dewatering and resedimentation was observed directly by the first author during a 1976 cruise to the Straits of Florida. During this cruise, piston cores with clear core liners were used to sample the foram-rich sediments from this region. Many of the recovered cores contained pockets of water between the sediment and the core liner. This sediment-laden water was observed migrating upwards along the coreliner-sediment boundary and the sediment was deposited as a new "coretop." At that time the effect was thought to be restricted to very coarse-fraction-rich sediments, but subsequent results on $\mathrm{V} 30-41 \mathrm{~K}$ and other cores indicate this may be more common than realized previously. In all subsequent discussions we consider the $2 \mathrm{~cm}$ level to be the true coretop for V30-41 K.

Resedimented material at the coretop could explain many of the apparently old ${ }^{14} \mathrm{C}$ ages for coretops that previously were ascribed to a lack of true coretop recovery due to overpenetration of the coring device. Also, this mechanism could explain the anomalously thick mixed layers required by Peng et al (1979) to model many coretop ${ }^{14} \mathrm{C}$ ages.

\section{Beta-Decay vs AMS Bulk ${ }^{14}$ C Dates}

The age-depth relationship of these analyses is shown in Figure 2. A distinct $4-6 \mathrm{~cm}$ bioturbated mixed layer is observed, which agrees with the ca $4 \mathrm{~cm}$ mixed layer estimated for this core by Jones and Ruddiman (1982). 
From $2-42 \mathrm{~cm}(i e$, ca $20,000 \mathrm{BP}$ ), there is little difference at the $1 \sigma$ level between these two methods. However, for sediments $>20,000 \mathrm{yr}$, the betadecay bulk ages increase more slowly than the accelerator bulk ages that continue to increase linearly (Fig 2).

Since both methods date the same material and are calibrated and checked through analyses of standards and blanks, we believe that one possible explanation for these results lies in the nature of the sampling. Samples for AMS dating were collected from the center of the Kasten core, whereas the ca $40 \mathrm{~g}$ samples for the beta-decay analyses were slices of each dated level in the core. Despite removing all sediment from the outer edge of the sample that was in contact with the core barrel, and all sediment surfaces exposed during core storage, it is possible that these large samples may contain 1-2\% of modern contamination (Fig 3).

This is an example, however, where accelerator ${ }^{14} \mathrm{C}$ dating of even bulk sediment can easily result in more realistic ages than the beta-decay methods for sediments $>20,000-25,000 \mathrm{yr}$. The smaller sample size requirement results in greater freedom in selecting the exact location of the sample to be taken at a particular horizon. If one had used the beta-decay dates as obtained, the interpretation would have been that $>18,000$-yr-old glacial sediments had accumulated at higher rates than during the last 18,000 yr. The accelerator dates on both bulk sediment and the $>150 \mu$ fraction suggest that, at this location, the ca $2.40 \mathrm{~cm} / 1000 \mathrm{yr}$ sedimentation rate has changed little during the last $35,000 \mathrm{yr}$.

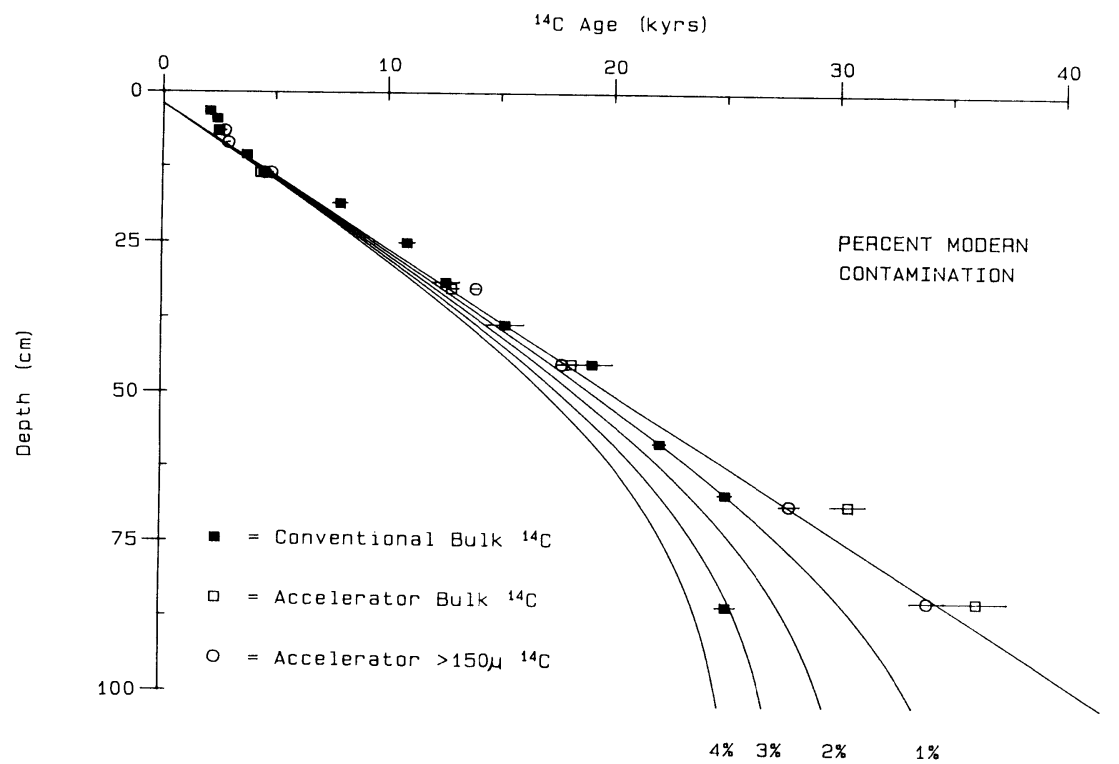

Fig 3. Age-depth plot for ${ }^{14} \mathrm{C}$ analyses listed in Table 1. Five curves are based on a uniform sedimentation rate of $2.4 \mathrm{~cm} / 1000 \mathrm{yr}$, and the effects of varying amounts $(0-4 \%)$ of modern ${ }^{14} \mathrm{C}$ contamination on measured ${ }^{14} \mathrm{C}$ ages. $1 \sigma$ errors are given as horizontal bars through each data point. Note increasingly divergent accelerator and conventional ${ }^{14} \mathrm{C}$ ages below $60 \mathrm{~cm}$. 
There are many examples of apparent sedimentation rate increases, age reversals and ${ }^{14} \mathrm{C}$ ages that are inconsistent with other stratigraphic information in the 25,000-35,000 yr age range when dating organic carbon and carbonate materials (eg, Geyh, Krumbein \& Kudrass, 1974; Geyh, 1979). This is one of the critical problems associated with ${ }^{14} \mathrm{C}$ dating older deep-sea sediments by beta-decay methods. It is well known that the sediment in contact with the core barrel is often contaminated with recent material as a result of the coring process. It is a standard procedure when sampling a deep-sea core to remove ca $0.25-0.5 \mathrm{~cm}$ from this outer layer of potentially contaminated material. However, in trying to date older core material, larger sample sizes are required to insure sufficient beta decays for meaningful counting statistics within a reasonable time. Therefore, as sample size increases, either stratigraphically thicker samples must be taken, thus reducing the chronologic resolution that can be obtained, or more material is obtained from a given horizon by sampling closer to the outer layer of the core, thus increasing the chance of contamination with modern sediment found along the inner lining of the core barrel. The AMS samples were no larger than $40 \mathrm{mg}$. Even for the oldest material, AMS requires only a very small segment of sediment $(<1 \mathrm{~cm})$ from the central region of the core.

\section{Iron-Carbide vs Graphite Targets}

The Arizona Accelerator Facility was in the process of switching from iron-carbide to graphite targets at the time Woods Hole Oceanographic Institution was preparing to use AMS in marine sedimentologic studies. We chose six levels from core V30-41 K to compare directly these two methods of AMS target preparation (Table 1). Iron-carbide targets yield ages that are systematically older than graphite targets, although still within the $1 \sigma$ counting statistics. The significant improvement in both the analytical precision and the extended background ages with graphite targets is readily apparent from the data in Table 1. The Arizona Accelerator Facility had analyzed ca 1000 samples between May 1982 and late 1984 with the ironcarbide targets before switching to graphite targets. None of the Woods Hole sedimentologic or paleoceanographic studies were done with ironcarbide targets.

\section{AMS Bulk vs AMS $>150 \mu$ Fraction Ages}

Several authors have discussed the problem of ${ }^{14} \mathrm{C}$ dating the carbonate fraction of marine sediments (eg, Emery \& Bray, 1962; Olsson \& Eriksson, 1965; Geyh, 1979; Erlenkeuser, 1979). Much of the problem involves incorporating reworked fine-grained detrital material $\left(i e,{ }^{14} \mathrm{C}\right.$ dead), resulting in anomalously old ${ }^{14} \mathrm{C}$ ages, age reversals, and/or uninterpretable records (eg, Geyh, 1979; Stanley, Nelson \& Stuckenrath, 1984; Stanley, 1985). The AMS method allows specific-size fractions and sediment components to be isolated and dated, thus offering a relatively straightforward method of eliminating the effects of detrital carbonate on ${ }^{14} \mathrm{C}$ ages.

As stated earlier, core V30-41 K was collected from a region characterized by minimal detrital carbonate input. As such, this core offers a good 
test of how bulk and coarse-fraction ${ }^{14} \mathrm{C}$ ages compare. The ages obtained from these two different fractions of the deep-sea sediment record reveal significant differences. For those sediments younger than the HoloceneLate Pleistocene transition (ie, ca 11,000 BP), the bulk sediment ages are younger than the coarse-fraction ages. For those sediments older than the Holocene-Late Pleistocene transition, the coarse-fraction dates are younger than the bulk sediment dates by as much as $2500 \mathrm{yr}$ (Fig 4).

One possible explanation for these age differences is that they are an artifact of the bioturbation-abundance couple (Hutson, 1980; Andrée et al, 1984; Peng \& Broecker, 1984). More Holocene coarse-fraction-rich sediment is mixed downward into the glacial-age sediments than glacial-age coarse-fraction material is mixed upwards into the Holocene sediments. This could result in glacial-age coarse-fraction dates younger than the true age for these sediments. The same would be true for the total $\mathrm{CaCO}_{3}$ fraction dates. The coarse-fraction percentages range from ca $10 \%$ in the last glacial to ca $40 \%$ in the Holocene (Fig 1), for an "abundance" change of $4.0 \mathrm{x}$. The carbonate percentages range from ca $60 \%$ in the last glacial to ca $90 \%$ in the Holocene (Fig 1), for an "abundance" change of 1.5x. The different magnitudes in abundance change across the glacial-Holocene transition will lead to differences in the ${ }^{14} \mathrm{C}$ ages of these two components.

Using the bioturbation model of Berger and Heath (1968), a $4 \mathrm{~cm}$ mixed layer, a sedimentation rate of $2.40 \mathrm{~cm} / 1000 \mathrm{yr}$ and the above-mentioned changes in carbonate and coarse-fraction percentages, the maximum model age difference between the two fractions occurs at the transi-

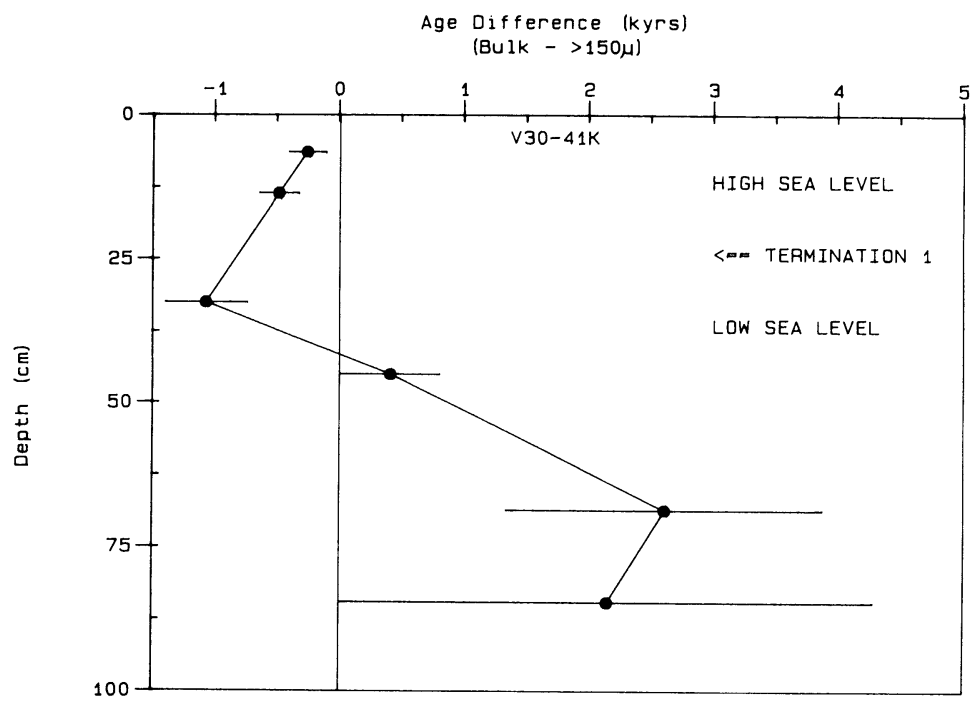

Fig 4. Age difference between the bulk (total) carbonate and the $>150 \mu$ fraction AMS $^{14} \mathrm{C}$ analyses. Note that for sediments shallower than $35 \mathrm{~cm}$ (ca 14,000 yr), the bulk fraction is older than the $>150 \mu$ fraction, whereas below this depth, the bulk fraction is younger than the $>150 \mu$ fraction. 
tion from glacial to Holocene values (ie, Termination 1) and is ca $300 \mathrm{yr}$. However, the model shows the coarse-fraction dates are younger than the bulk-carbonate dates at this transition. This result is the opposite of what is observed. Even using much thicker mixed layers, we could not duplicate the observed age differences between these two sediment components.

A second possible explanation for these age differences is that there is a significant component of reworked detrital carbonate in the fine fraction. The source of this material would be eolian dusts from the African continent (Prospero, Glaccum \& Nees, 1981). Although it is difficult to determine quantitatively the detrital vs biogenic carbonate contributions to these sediments, we can estimate the detrital contribution from published data. Curry and Lohmann (1986) have determined the relationship of wet and dry bulk density to carbonate percentage for a series of cores from the nearby Sierra Leone Rise $\left(\mathrm{ca} 4^{\circ} \mathrm{N}, 21^{\circ} \mathrm{W}\right)$. Using the $\mathrm{CaCO}_{3}$ percentages determined for V30-41 K and the equation of Curry and Lohmann (1986) we can calculate the wet and dry bulk density for V30-41 K.

Kolla, Biscaye \& Hanley (1979) determined the accumulation rates of quartz for several Eastern Equatorial Atlantic cores. Core A180-73 $\left(00^{\circ} 10^{\prime} \mathrm{N}, 23^{\circ} 0^{\prime} \mathrm{W}\right) 3749 \mathrm{~m}$ water depth, is from the same location as V30$41 \mathrm{~K}$ and has a Holocene quartz accumulation rate of $10 \mathrm{mg} \mathrm{cm}^{-2} \mathrm{ky}^{-1}$. The quart $z$ accumulation rate for the last glacial was $60 \mathrm{mg} / \mathrm{cm}^{-2} \mathrm{ky}^{-1}$. The source of this material is wind-blown dusts from the African continent. Prospero, Glaccum \& Nees (1981) showed that the mineralogy of dusts advected from Africa have a quartz/calcite ratio of ca 2.0. This dust composition is recorded in French Guiana, Barbados and Dakar, and remains seasonally little changed. We assume that the quartz/calcite ratio of African dusts has not changed between the last glacial and the Holocene.

Using these measurements, we can calculate that $<0.2 \%$ of the carbonate in the Holocene interval of V30-41 K is detrital, and for the last glacial, ca $2 \%$ is detrital carbonate. Using these estimates of detrital (ie, ${ }^{14} \mathrm{C}$-dead) carbonate and the fact that the $>150 \mu$ fraction of these sediments contains no detrital carbonate and should thus reflect a more realistic estimate of the "true" age of the sediments at each of the dated levels, we cannot reconcile the magnitude of the observed age differences. Although the effect is in the right direction to explain glacial bulk samples older than coarsefraction samples, $>20 \%$ of the glacial-age carbonate would have to be detrital in order to explain the observed age differences.

A third possible explanation is that carbonate dissolution could differentially affect the ${ }^{14} \mathrm{C}$ age of different size fractions and sediment components. Models have been developed to explain the dissolution effect on mixed-layer ages (Sundquist et al, 1977; Broecker \& Peng, 1982; Berger \& Killingley, 1982). If we assume that no dissolution occurred during the Holocene, and that the observed downcore variations in carbonate percentage are solely the result of carbonate dissolution (an extreme and unrealistic assumption), we can calculate the age of the Holocene mixed layer to be ca $1550 \mathrm{yr}$ using the model of Broecker and Peng (1982). This age closely agrees with the measured value of $1700 \mathrm{yr}$ ( $i e$, the 2100 -yr value reported in Table 1 minus the 400-yr ocean reservoir correction). Assum- 
ing dissolution is the sole contributor to the observed carbonate percentage record, we would calculate a paleo-mixed-layer age for the last glacial as ca 75 yr. Thus, dissolution could cause a maximum 1500-yr shift in the age of a given horizon but does not explain the age difference between two different carbonate components from the same horizon.

We are unable to explain why bulk sediment ages are younger than coarse-fraction ages for the Holocene, but older than the coarse-fraction ages during the last glacial (Fig 4). We note that Andrée et al (1984) reported similar results for fine-fraction/coarse-fraction analyses from coretop and mid-Holocene levels in a core from the equatorial Pacific. In addition, Andrée et al (1984) showed a downcore trend of increasing agedifferences for dissolution-resistant vs dissolution-susceptible foraminiferal species similar to that seen for coarse-fraction $v s$ bulk-sediment ages. It is impossible at present to evaluate the role of dissolution in explaining the data presented here and in Andrée et al (1984).

The data we have obtained from core V30-41 K points out how complicated even simple and potentially easily explained sedimentary environments can be. We suspect that bioturbation, detrital $\mathrm{CaCO}_{3}$, dissolution and other factors all play a role in answering the up to $20 \%$ age differences observed between different components from the same horizon. This study was designed to compare the beta-decay and AMS methods of ${ }^{14} \mathrm{C}$ dating deep-sea sediments, and not to evaluate the depositional and post-depositional processes occurring on the sea floor. However, it is clear that AMS studies must be designed to evaluate the role of these processes if we are to be able to interpret and understand the deep-sea sediment ${ }^{14} \mathrm{C}$ record.

\section{CONCLUSIONS}

For chronostratigraphic purposes, there is no unambiguous method of determining precisely the "true" ${ }^{14} \mathrm{C}$ age for any horizon within a deepsea-sediment core. Age differences of several thousand years have been obtained from different components collected from the same stratigraphic horizon. The overall sedimentation rate can be determined quite well with AMS and appears to be superior to the beta-decay method from the standpoint of sample size and the greater chance of routinely obtaining accurate ${ }^{4} \mathrm{C}$ dates from the interval $25,000-40,000$ BP. Very thin horizons can be dated while, at the same time, leaving a substantial portion of the sediment from that horizon for other paleoceanographic and sedimentologic studies. This method eliminates much of the interpolation that has to be done with beta-decay methods where a horizon several $\mathrm{cm}$ thick from a core can be consumed for a single ${ }^{14} \mathrm{C}$ date.

On the other hand, the small sample-size requirements of the AMS method can cause problems. Inhomogeneities, such as burrows that are preserved in the sediment record, become important relative to the required sample size. With much larger sample sizes for conventional dating, these type of inhomogeneities are averaged and the measured ${ }^{14} \mathrm{C}$ age becomes a good approximation of the level dated.

The great interest in the AMS ${ }^{14} \mathrm{C}$ dating of deep-sea sediments is not in obtaining a routine chronostratigraphy, rather it is in using this method 
for studying in detail the timing and duration of rapidly occurring climatic events, climatic lead-lags and regional temporal variability of climatic events. It is just these type of studies that must be evaluated very carefully before meaningful interpretations can be made.

\section{ACKNOWLEDGMENTS}

We thank L Toolin and A Hatheway for assistance in sample preparation and analysis, and A Gagnon for figure preparation. This research was supported by the Office of Sea Grant in the National Oceanic and Atmospheric Administration through grant NA-84AA-D-00033 (R/G-10) to G Jones, and NSF grants EAR-83-09448 and EAR-85-12761 to the Arizona Accelerator Facility. This is Woods Hole Oceanographic Institution contribution no. 6749 .

\section{REFERENCES}

Andrée, M, Beer, J, Oeschger, H, Broecker, W S, Mix, A, Ragano, N, O'Hara, P, Bonani, G, Hofmann, H J, Morenzoni, E, Nessi, M, Suter, M and Wölfli, W, 1984, ${ }^{14}$ C measurements of foraminifera of deep sea core V28-238 and their preliminary interpretation: Nuclear Instruments \& Methods, v B5, p 340-345.

Andrée, M, Oeschger, H, Broecker, W S, Beavan, N, Mix, A, Bonani, G, Hofmann, H J, Morenzoni, E, Nessi, M, Suter, M and Wölfli, W, 1986, AMS radiocarbon dates on foraminifera from deep sea sediments, in Stuiver, M and Kra, R S eds, Internatl ${ }^{14} \mathrm{C}$ conf, 12 th, Proc: Radiocarbon, v 28, no. 2A, p 424-428.

Arrhenius, G, Kjellberg, G and Libby, W F, 1951, Age determination of Pacific chalk ooze by radiocarbon and titanium content: Tellus, v 3, p 222-229.

Bard, E, Arnold, M, Maurice, P, Duprat, J, Moyes, J and Duplessy, J, 1987, Retreat velocity of the North Atlantic Polar Front during the last deglaciation determined by ${ }^{14} \mathrm{C}$ accelerator mass spectrometry: Nature, v 328, p 791-794.

Barker, H, 1953, Radiocarbon dating: Large-scale preparation of acetylene from organic material: Nature, v 172, no. 4379, p 631-632.

Bennett, C I, Beukens, R P, Clover, M R, Elmore, D, Gove, H E, Kilius, L, Litherland, A E and Purser, K H, 1978, Radiocarbon dating with electrostatic accelerators: Dating of milligram samples: Science, v 201, p 345-347.

Bennett, C L, Beukens, R P, Clover, M R, Gove, H E, Liebert, R B, Litherland, A E, Purser, K H and Sondheim, W E, 1977, Radiocarbon dating using electrostatic accelerators: Negative ions provide the key: Science, v 198, p 508-510.

Berger, R and Suess, H E, eds, 1979, Radiocarbon dating, Internatl ${ }^{14} \mathrm{C}$ conf, 9th, Proc: Berkeley, Univ California Press, $787 \mathrm{p}$.

Berger, W H and Heath, G R, 1968, Vertical mixing in pelagic sediments: Jour Marine Research, v 26, p 134-143.

Berger, W H and Killingley, J S, 1982, Box cores from the equatorial Pacific: ${ }^{14} \mathrm{C}$ sedimentation rates and benthic mixing: Marine Geol, v 45, p 93-125.

Blomqvist, $S, 1985$, Reliability of core sampling of soft bottom sediment-an in situ study: Sedimentology, v 32, p 605-612.

Broecker, W, Mix, A, Andrée, M and Oeschger, H, 1984, Radiocarbon measurements of coexisting benthic and planktic foraminifera shells: Potential for reconstructing occan ventilation times over the past 20,000 years: Nuclear Instruments \& Methods, v B5, p 331 339.

Broecker, W S, Ewing, M and Heezen, B C, 1960, Evidence for an abrupt change in climate close to 11,000 years ago: Am Jour Sci, v 258, p 429-448.

Broecker, W S and Peng, T-H, 1982, Tracers in the sea: Palisades, New York, Eldigio Press, $690 \mathrm{p}$.

Burns, R E, 1963, A note on some possible misinformation from cores obtained by piston-type coring devices: Jour Sed Petrol, v 33, p 950-952.

Curry, W B and Lohmann, G P, 1986, Late Quaternary carbon sedimentation at the Sierra L.eone rise (Eastern equatorial Atlantic Ocean): Marine Geol, v 70, p 223-250.

Duplessy, J, Arnold, M, Maurice, P, Bard, E, Dupra, J and Moyes, J, 1986, Direct dating of the oxygen-isotope record of the last deglaciation by ${ }^{14} \mathrm{C}$ accelerator mass spectrometry: Nature, v 320, no. 6060, p 350-352.

Emery, K O and Bray, F. F, 1962, Radiocarbon dating of California Basin sediments: Bull Am Assoc Petroleum Geologists, v 46, p 1839-1856. 
Emery, K O and Hulsemann, J, 1964, Shortening of sediment cores collected in open barrel gravity corers: Sedimentology, v 3, p 144-154.

Ericson, D B, Broecker, W S, Kulp, J L and Wollin, G, 1956, Late-Pleistocene climates and deep-sea sediments: Science, v 124, no. 3218, p 385-389.

Erlenkeuser, H, 1979, Environmental effects on radiocarbon in coastal marine sediments, in Berger, R and Suess, H, eds, Radiocarbon dating, Internatl ${ }^{14} \mathrm{C}$ conf, 9 th, Proc: Berkeley, Univ California Press, p 453-469.

Faure, G, 1977, Principles of isotope geology: New York, John Wiley \& Sons, Inc, $464 \mathrm{p}$.

Geyh, M A, $1979,{ }^{14} \mathrm{C}$ routine dating of marine sediments, in Berger, R and Suess, H, eds, Radiocarbon dating, Internatl ${ }^{9} \mathrm{C}$ conf, 9th, Proc: Berkeley, Univ California Press, p 470-491.

Geyh, M A, Krumbein, W E and Kudrass, H-R, 1974, Unreliable ${ }^{14} \mathrm{C}$ dating of long-stored deep-sea sediments due to bacterial activity: Marine Geol, v 17, p M45-M50.

Hopkins, T L, 1964, A survey of marine bottom samplers: Prog Oceanog, v 2, p 213-256.

Hutson, W H, 1980, Bioturbation of deep-sea sediments: Oxygen isotopes and stratigraphic uncertainty: Geology, v 8, p 127-130.

Jones, G A and Kaiteris, P, 1983, A vacuum-gasometric technique for rapid and precise analysis of calcium carbonate in sediment and soils: Jour Sed Petrol, v 53, p 655-660.

Jones, G A and Ruddiman, W F, 1982, Assessing the global meltwater spike: Quaternary Research, v 17, p 148-172.

Jull, A J T, Donahue, D J, Hatheway, A L, Linick, T W and Toolin, L J, 1986, Production of graphite targets by deposition from $\mathrm{CO} / \mathrm{H}_{2}$ for precision accelerator ${ }^{14} \mathrm{C}$ measurements, in Stuiver, $\mathrm{M}$ and $\mathrm{Kra}, \mathrm{R} \mathrm{S}$, eds, Internatl ${ }^{14} \mathrm{C}$ conf, 12 th, Proc: Radiocarbon, v 28, no. $2 \mathrm{~A}$, p 191-197.

Kolla, V, Biscaye, P E and Hanley, A F, 1979, Distribution of quartz in late Quaternary Atlantic sediments in relation to climate: Quaternary Research, v 11, p 261-277.

Libby, W F, 1955, Radiocarbon dating, 2nd ed: Chicago, Univ Chicago Press, 175 p.

Linick, T W, Jull, A J T, Toolin, L J and Donahue, D J, 1986, Operation of the NSF-Arizona accelerator facility for radioisotope analysis and results from selected collaborative research projects, in Stuiver, $\mathrm{M}$ and $\mathrm{Kra}, \mathrm{R} S$ eds, Internatl ${ }^{14} \mathrm{C}$ conf, 12 th, Proc: Radiocarbon, v 28, no. 2A, p 522-533.

Olsson, I U and Ericksson, K G, 1965, Remarks on ${ }^{14} \mathrm{C}$ dating of shell material in sea sediments: Prog Oceanog, v 3, p 253-266.

Peng, T-H and Broecker, W S, 1979, Rates of benthic mixing in deep-sea sediment as determined by radioactive tracers: Quaternary Research, v 11, p 141-149. 1984 , The impacts of bioturbation on the age difference between benthic and planktonic foraminifera in deep sea sediments: Nuclear Instruments \& Methods, v B5, p 346-352.

Peng, T-H, Broecker, W S, Kipphut, G and Shackleton, N, 1979, Benthic mixing in deep sea cores as determined by ${ }^{14} \mathrm{C}$ dating and its implications regarding climate stratigraphy and the fate of fossil fuel $\mathrm{CO}_{2}$, in Andersen, $\mathrm{N} \mathrm{R}$ and Malahoff, A, eds, The fate of fossil fuel $\mathrm{CO}_{2}$ in the oceans: New York, Plenum Press, p 355-373.

Prospero, J M, Glaccum, R A and Nees, R T, 1981, Atmospheric transport of soil dust from Africa to South America: Nature, v 289, p 570-571.

Slota, Jr, P J, Jull, A J T, Linick, T W and Toolin, L J, 1987, Preparation of small samples for ${ }^{14} \mathrm{C}$ accelerator targets by catalytic reduction of CO: Radiocarbon, v 29, no 2, p 303-
306 .

Stanley, D J, 1985, Mud redeposition and problems of assessing microfossil, isotopic and radiocarbon data in the Mediterranean: Marine Geol, v 62, p 381-389.

Stanley, D J, Nelsen, T A and Stuckenrath, R, 1984, Recent sedimentation on the New Jersey slope and rise: Science, v B226, no. 4671, p 125-133.

Stuiver, M and Ostlund, H G, 1980, GEOSECS Atlantic radiocarbon: Radiocarbon, v 22, no. $1, \mathrm{p} 1-24$.

Stuiver, $\mathrm{M}$ and Polach, H A, 1977, Discussion: Reporting of ${ }^{14} \mathrm{C}$ data: Radiocarbon, v 19, no. 3, p 355-363.

Suess, H E, 1954, Natural radiocarbon measurements by acetylene counting: Science, v 120, p 5-7.

Sundquist, E, Richardson, D K, Broecker, W S and Peng, T-H, 1977, Sediment mixing and carbonate dissolution in the southeast Pacific Ocean, in Andersen, N R and Malahoff, A eds, The fate of fossil fuel $\mathrm{CO}_{2}$ in the oceans: New York, Plenum Press, p 429-454.

Weaver, P P E and Schultheiss, P J, 1983, Detection of repenetration and sediment disturbance in open-barrel gravity cores: Jour Sed Petrol, v 53, p 649-678.

Wrath, W F, 1936, Contamination and compaction in core sampling: Science, v 84, p 537538. 